\title{
PRODUCTION AND PROMOTION OF TRITICALE AS A HIGH QUALITY FODDER AND FEED IN SMALL-SCALE DAIRY FARMERS OF BANGLADESH
}

\author{
M. E. Haque, S. R. Waddington, Z. I. Sarker ${ }^{1}$, N. R. Sarker ${ }^{2}$ and \\ M. Akteruzzaman ${ }^{3}$ \\ International Maize and Wheat Improvement Centre (CIMMYT), House-18, Road-4, \\ Sector-4, Uttara, Dhaka-1230, Bangladesh
}

\begin{abstract}
In Bangladesh, high quality fodder is scare from December to May for ruminant livestock and feed is expensive throughout the year for poultry. A project was conducted in the cool dry Rabi (December-February) seasons of 2005-06 and 2006-07 to promote triticale ( $\mathrm{X}$ Triticosecale Wittmack) as a high quality dual-purpose fodder and feed for small-scale dairy and poultry producers. During 2005 and 2006, 504 farm families from six districts in north western and central Bangladesh received training on triticale cultivation and its utilization as a green fodder for dairy cows and for grain. Printed training manuals and visual training materials (including a DVD docudrama) were developed, used in training, and distributed widely. On-farm demonstrations on triticale production were mounted with each trained farm family in two years using a dual-purpose fodder and grain type triticale variety, WRF-7, that earlier on farm research had identified to perform well in Bangladesh. High quality grass fodder was obtained by cutting the vegetative triticale plants either twice (at 35 and 50 days after seeding (DAS)) or once (at around 40 days), while the later ratooning tillers produced grain. In 168 farmer demonstrations in 2005-06, the green fodder yield ranged from 4.9 to $20.0 \mathrm{t} / \mathrm{ha}$ fresh mass ( $0.7 \mathrm{t} / \mathrm{ha}$ to $2.7 \mathrm{t} / \mathrm{ha}$ dry mass) from one cut at 35 DAS and 7 to $28 \mathrm{t} /$ ha fresh mass from two cuts at 35 and 50 DAS. Overall, $62 \%$ of farmers reported yields above $10 \mathrm{t} / \mathrm{ha}$ of fresh green fodder. A mean grain yield of 1.8 $\mathrm{t} /$ ha was obtained from WRF-7 after two cuts on-farm. Straw yields ranged from 0.8 to $7.1 \mathrm{t} /$ ha dry mass. 324 farmers hosted similar demonstrations in 2006-07 and reported higher yields of green fodder, ranging from 7.4 to $33.7 \mathrm{t} / \mathrm{ha}$ fresh mass from one cut at 40 to 42 DAS. A higher mean grain yield of $2.8 \mathrm{t} /$ ha was obtained from WRF-7 after one cut for fodder in 2006-07. Assessments of WRF-7 dual-purpose triticale by farmers were very positive, with $97 \%$ wanting to grow triticale again in more land ranging from 0.04 ha to 0.81 ha (Table 3). From experience, many farmers decided it was more efficient to cut triticale once for green fodder. Almost all farmers reported benefits to milk production and farm income from feeding triticale fodder to cows. It was concluded that smallholder dairy farmers in North-West Bangladesh can easily produce sufficient amounts of quality fodder for dairy cows and feed for poultry from WRF-7 dual-purpose triticale during periods of severe fodder shortages.
\end{abstract}

\footnotetext{
1 Bangladesh Agricultural Research Institute, Nashipur, Dinajpur-5200, Bangladesh

2 Bangladesh Livestock Research Institute, Savar, Dhaka-1341, Bangladesh

3 Department of Agriculture Economics, Bangladesh Agricultural University, Mymensingh-2202, Bangladesh
} 
Key words : Fodder, feed, triticale, dairy cows, poultry, whole-family training, on-farm demonstrations

\section{INTRODUCTION}

Dairy farming is an important part of the rice-based mixed farming systems in Bangladesh. A major constraint to the expansion of dairy holdings in Bangladesh is the scarcity of quality fodder, which is marked in a lean season from December to May (Saadullah, 2002; Haque et al. 2007). Triticale (X Triticosecale Wittmack) is a human-made cross between rye and durum wheat. It is characterized by good performance under unfavourable production conditions (including acidic soils and drought), an ability to produce higher biomass and high re-growth after grazing or cutting, and its usefulness as a feed grain for monogastric animals (Varughese et al., 1997). It is a useful dual-purpose crop for grain and forage biomass (Andrews et al., 1991). Triticale is relatively well known as a high quality green fodder or silage in temperate and Mediterranean Europe (Gentinetta et al., 1983; Mosimann, 1998), but less is known about its performance in sub-tropical environments.

Tests internationally and in Bangladesh have shown the quality of triticale green fodder to be similar to that from several forage legumes such as lathyrus (Lathyrus sativa) or ipilipil (Leucaena spp.) and well above grass forages, with $24.7 \%$ crude protein in the dry matter and metabolizable energy values of $10.6 \mathrm{MJ} / \mathrm{kg}$ dry matter (Gohl, 1981; Belaid, 1994; Flores et al., 1994; Haque et al., 2007). Triticale hay was also high quality, while the straw was twice as nutritious as rice or wheat straw and its grain contained more protein $(15.8 \%)$ than other cereals. Its fodder is rich in lysine and tryptophan; two amino acids essential for the growth and development of livestock. Initial feeding trials conducted by Bangladesh Livestock Research Institute (BLRI) and CIMMYT also indicated that cattle performance (as measured by live weight gain) can increase significantly and this contributed to higher dairy production (Sarker et al. 2007).

Triticale was introduced into Bangladesh in the mid 1970s and was found to grow well during the cool dry Rabi (November-March) season, giving grain yields similar to or above those from wheat (Sufian, 1979). The crop needs little management, and moderate amounts of fertilizer and water. It is able to produce two cuttings of quality green fodder at the time that small-scale dairy farmers face a severe shortage of quality fodder, while later in crop development, the ratooning tillers produce grain (Ahmed and Meisner, 2002; Haque et al., 2007). Staggered plantings of triticale from early November to mid December provide a steady fodder supply in the lean season. The national Wheat Research Centre of Bangladesh Agricultural Research Institute (BARI) has released a dual-purpose triticale, WRF-7 (originally from CIMMYT), that has performed well under research conditions. During 1999-2002, when WRF-7 triticale was assessed in Bangladesh as a dual-purpose quality fodder and grain crop during the lean season, high quality grass fodder was obtained by cutting green triticale plants twice, at 35 and 50 days after seeding. In 54 on farm demonstrations conducted throughout Bangladesh in 2001-02, 6-15 t/ha of fresh mass fodder was produced from two cuts within 50 days after sowing (Fig. 1) (Haque 
et al., 2007). After two cuts, WRF-7 triticale crops then grew on to yield 1.1-2.4 t/ha of grain for poultry feed or human food, which was about 30\% more than from the grain triticale BAT-1 (Fig. 2) (Jahan et al., 2001; Haque et al., 2007). Thus, WRF-7 dual-purpose triticale was identified as an exciting new option with great potential to significantly reduce fodder and feed scarcity in Bangladesh during the Rabi season, and thereby increase smallholder milk and meat production (Ahmed and Meisner, 2002; Jahan et al., 2001; Haque et al., 2007).

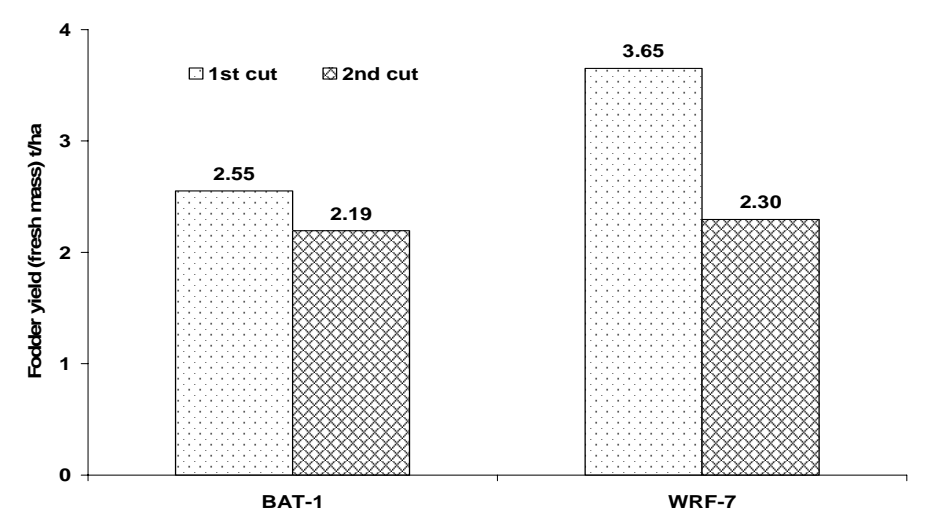

Fig. 1. Mean fodder yield (fresh mass) of BAT-1 triticale in seven demonstrations and WRF-7 triticale in 44 demonstrations of NW, central and SW eleven districts of Bangladesh, 2001-02

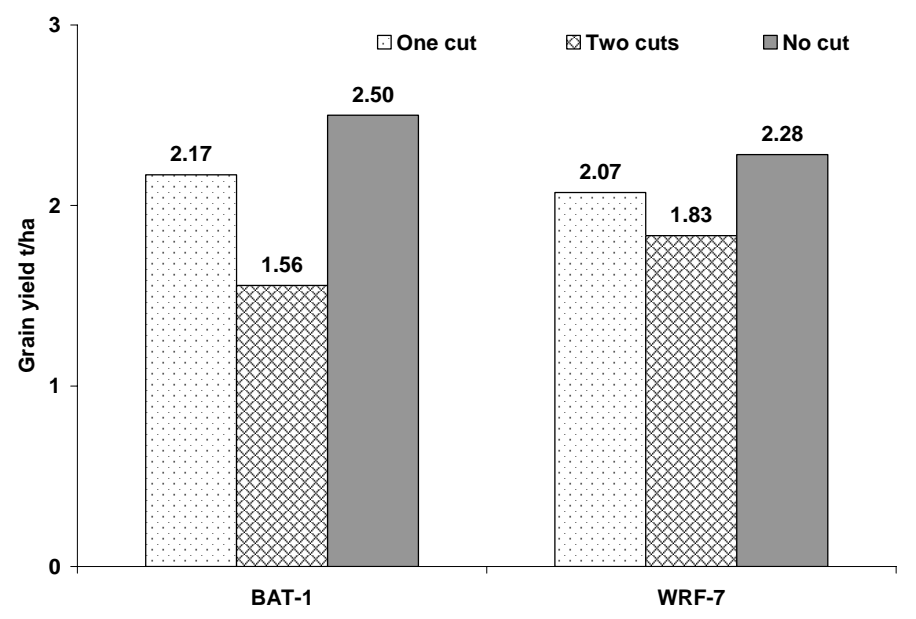

Fig. 2. Mean grain yield ( $t /$ ha) of BAT-1 triticale in seven demonstrations and WRF-7 triticale in 44 demonstrations of NW, central and SW eleven districts of Bangladesh 2001-02

To promote dual-purpose triticale as a lean season high quality fodder and feed for smallscale dairy and poultry production in Bangladesh, we undertook a project in the 2005-06 
and 2006-07 Rabi seasons, with financial support from DANIDA. The project involved government agricultural research (Wheat Research Center of BARI, Bangladesh Livestock Research Institute (BLRI)) and extension agencies (Department of Livestock Services (DLS)), two international research centres (CIMMYT and ILRI), milk marketing organizations (Milk Vita and Bangladesh Rural Advancement Committee (BRAC)) and farmer groups.

Fodder producers and users from areas that are ecologically suitable for fodder cultivation and that have a high demand for green fodder for dairy cows and grain for poultry feed were identified. Farmer selection was conducted by DLS, Milk Vita and BRAC field staff in October 2005 and September 2006, prior to the start of the triticale production season. Selected farm families had to have between two and ten milking cows, at least $800 \mathrm{~m}^{2}$ of arable land that they would commit for fodder production and an interest to participate in and learn from the training. During the 2005-06 Rabi season, the program worked in four districts (Rangpur, Joypurhat, Pabna and Shirajgonj) of North Western Bangladesh; with 48 farm families in each district. This was expanded to six districts for the 2006-07 Rabi season, with the addition of Faridpur and Madaripur districts in West Central Bangladesh. Work during 2006-07 involved 54 farm families in each district, making a total of 504 farm families in the two years.

For the 2005-06 Rabi season, four training-of-trainer workshops for staff from the Department of Livestock Services (DLS), Milk Vita and BRAC were completed during September and October 2005 on the project theme, activities and whole-family training methodology (Meisner et al., 2003) in Joypurhat, Rangpur, Pabna and Shirajgonj districts. Forty-two Officers and Field Organizers from DLS, BRAC and Milk Vita participated. These staff then conducted whole family training during October 2005 with 168 farmfamilies from the four North West Bangladesh districts covering triticale fodder and grain production and its utilization for feeding dairy cows. Initially, 141 of these farm families completed a pre-training survey questionnaire on cattle herds, fodder demand and supply, knowledge on fodder production, milk production and milk marketing. For the 2006-07 Rabi season, a further 342 new farm families from the six districts received training in triticale fodder production and utilization during October and November 2006. Each year we organized and conducted three Field Days, which exposed around 1200 additional farmers to triticale production and utilization.

Each whole-family training session took place over half a day with 8-10 farm families and the participation of 3-4 adult male and female members from each family. Farmers received information and asked questions about the production of green leaf fodder and grain from triticale. Land preparation, planting techniques, fertilizer use, irrigation and weed management were all covered. Farmers were shown when and how to cut the green fodder twice at 35 and 50 DAS. Further information was given on how farmers should feed triticale to their cows and the benefits to expect. Information on silage and hay making techniques was also provided. The harvest and uses of triticale grain were discussed, as well as the need to preserve some seed for replanting. 
A range of training materials were developed for and used in the whole-family training and in broader awareness on triticale as a fodder. A high quality colour pictorial training manual was developed during October 2005 to February 2006. Three thousand copies were printed and distributed during March and April 2006 and used in whole family training for the 200607 season. Video footage of triticale production and utilization was shot on location several times during the 2005-06 Rabi season and Bangladesh Television (BTV) telecasted different triticale project activities at five times nationally. Additional video shooting on triticale production and utilization using actors was completed during the 2005-06 Rabi season and developed into a high quality 31-minute "Docu Drama". This has been shown at numerous publicity and training events, including all the whole-family training sessions during the 2006-07 Rabi season.

\section{MATERIALS AND METHODS}

An on-farm demonstration of triticale production was prepared for the 2005-06 season, and given to each of 180 families that had participated in whole-family training. Each family received sufficient seed (at $120 \mathrm{~kg} / \mathrm{ha}$ ) of WRF-7 (dual fodder and grain type triticale) and fertilizer (at 100-60-40-20 kg/ha NPKS) to plant $800 \mathrm{~m}^{2}$ of land. A copy of the triticale production and utilization manual and a signboard were also given. Two-thirds of the $\mathrm{N}$ and all the PKS was applied as a basal dressing before final land preparation. All except two farmers grew the triticale. Most of the demonstrations were planted within the recommended period of 17 November to 10 December 2005. The first irrigation was given at the crown root initiation (CRI) stage followed by a top dress of the remaining $\mathrm{N}$ as urea. All participating families cut triticale leaves from the demonstrations and fed the fodder to their cows from December 2005 to February 2006. The triticale plants were cut $4 \mathrm{~cm}$ above ground level at the first cut (35 DAS) and $8 \mathrm{~cm}$ at the second cut (50 DAS). After each cutting for green fodder, a light irrigation was given followed by an extra top dress of $50 \mathrm{~kg} / \mathrm{ha}$ urea. Most farmers irrigated once again during the early grain filling stage. Farmers were trained by extension staff to measure green fodder, grain and straw yields from their fields. Data were obtained from 149 farms after triticale grain harvest in 2005-06. These assessments were verified at some sites through crop cuts made by research and extension staff. From oven dried samples, we calculated first cut fodder dry mass $=12-15 \%$ of fresh mass and second cut fodder dry mass $=17-18 \%$ fresh mass.

For the 2006-07 Rabi season, 324 new farmers each hosted an on-farm triticale demonstration that was very similar to those conducted in 2005-06 except the cutting practice. Feedback from many farmers in 2005-06 favoured one cut (not two) for fodder, to also produce high yielding bold grains. Based on experiences and new recommendations in many training sessions, most farmers in 2006-07 harvested green fodder once at 40 to 42 DAS leaving the $5-6 \mathrm{~cm}$ bottom portion of triticale plants to regrow grain. After triticale production season, data were collected from 235 triticale growers of 2006-07 and reported in the paper.

Additional triticale seed production initiatives were conducted for the program. Five ha of triticale was grown for seed production at the Wheat Research Centre, Nashipur, 
Regional Agricultural Research Station (RARS) of BARI, Jamalpur and Bangladesh Livestock Research Institute during 2005-06. A further 3 ha of triticale seed production fields were planted during 2006-07 at Wheat Research Sub-station Dinajpur, 1 ha at RARS Jamalpur and 7.3 ha in 18 block demonstrations, with one block in each upazila of the six selected districts.

\section{RESULTS}

In the on-farm demonstrations with WRF-7 during 2005-06, the green fodder yield ranged from 4.9 to $20.0 \mathrm{t} /$ ha fresh mass ( 0.7 to $2.7 \mathrm{t} /$ ha dry mass) from one cut at 35 DAS and 7.0 to $28.0 \mathrm{t} / \mathrm{ha}$ fresh mass from two cuts at 35 and 50 DAS (Fig. 3). Overall, 62\% of farmers reported getting more than $10 \mathrm{t} /$ ha of fresh fodder in 2005-06 (Fig. 3). Although grain yield and grain-size decreased with late planting, and with increased frequency and later timing of grass cutting, high grain yields (up to $3.5 \mathrm{t} /$ ha with a mean of $1.8 \mathrm{t} / \mathrm{ha}$ ) were obtained from WRF-7 after two cuts on-farm (Fig. 4). Thirty-one percent of farmers reported grain yields of $2-3 \mathrm{t} / \mathrm{ha}$, while $64 \%$ obtained 1-2 t/ha (Fig. 4). Straw yields ranged from 0.8 to $7.1 \mathrm{t} /$ ha dry mass (Fig. 5).

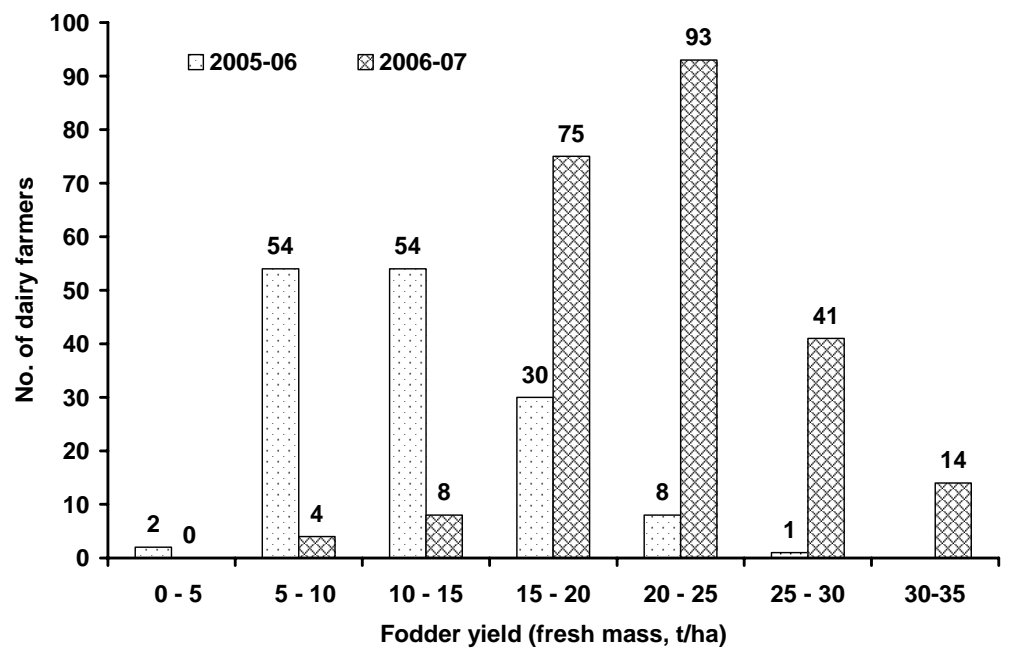

Fig. 3. Distribution of fodder yield (fresh mass, $t /$ ha) of WRF-7 triticale in 145 demonstrations in 2005-06 and 235 demonstrations in 2006-07 of NW, central and SW six districts of Bangladesh

Triticale fodder yields were measured on most of the 2006-07 on-farm demonstrations. All except 8 farmers made one cut. Fresh fodder yields were considerably higher than the previous year and ranged from 7.4 to $33.7 \mathrm{t} /$ ha (Fig. 3). In 2006-07 an estimated $81.5 \mathrm{t}$ of triticale grain was produced by farmers participating in the demonstration program. Grain yields in 2006-07 ranged from 1.19 to $5.9 \mathrm{t} /$ ha with a mean of $2.8 \mathrm{t} / \mathrm{ha}$, which was $55.6 \%$ higher than 2005-06 (Fig. 4). The straw yields were 2.2 to $6.8 \mathrm{t} /$ ha in 2006-07 (Fig. 5). 
During 2006-07, farmers reported the triticale grain produced in the six districts was utilized as follows; $23 \%$ was sold to other farmers, $23 \%$ fed to cattle or poultry, $23 \%$ as human food, $25 \%$ seed for next year cultivation, and the remaining $6 \%$ for other purposes. Many growers were interested to try triticale grain as human food. A doubleblind taste test with farmers showed that 'chapattis' made with 50 wheat: 50 triticale flour were consistently selected as the best indicating that triticale grain could be acceptable to make flat breads for human consumption in Bangladesh.

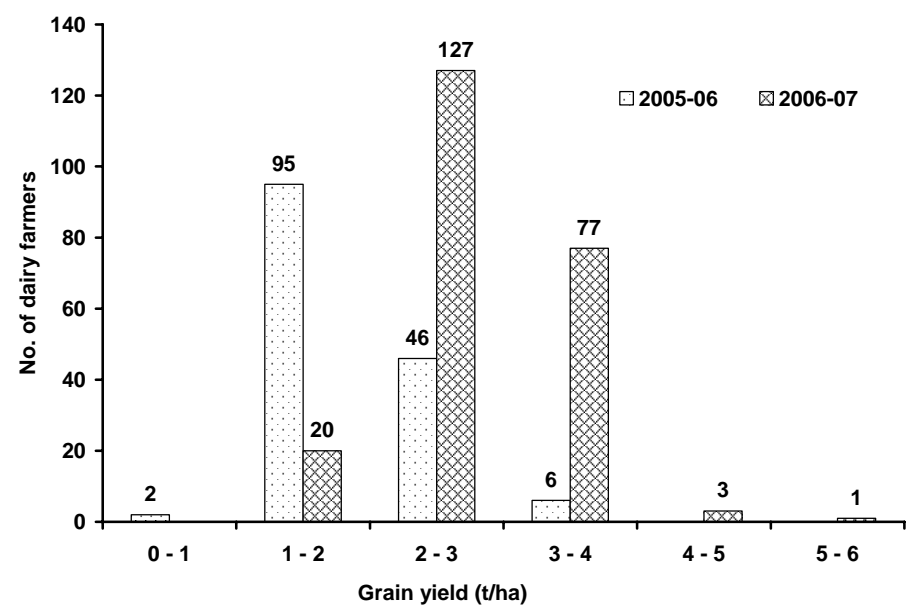

Fig. 4. Distribution of grain yield ( $\mathrm{t} / \mathrm{ha}$ ) of WRF-7 triticale in 145 demonstration in 2005-06 and 228 demonstration in 2006-07 of NW, central and SW six districts of Bangladesh

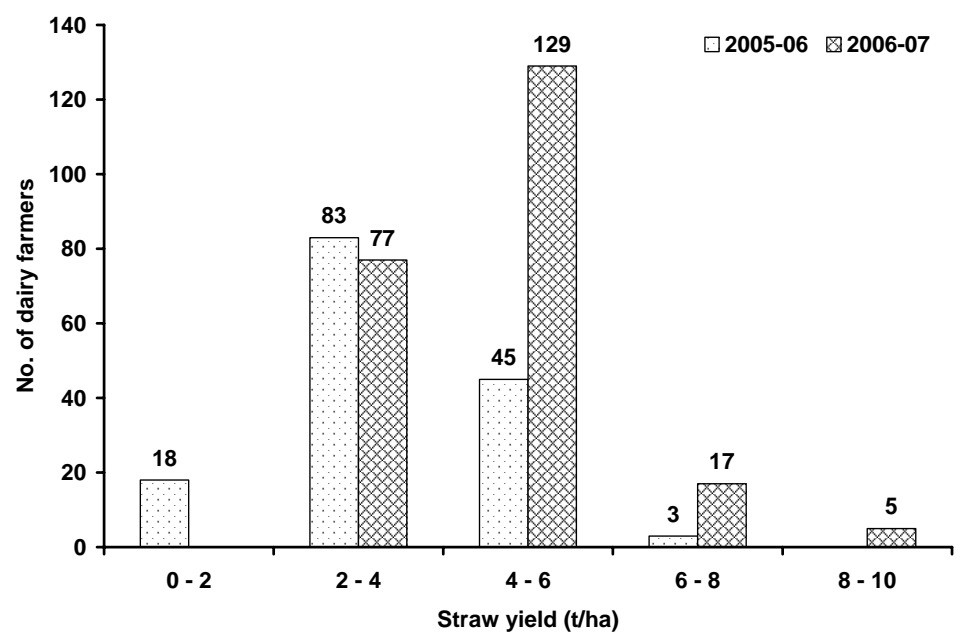

Fig. 5. Distribution of straw yield ( $t /$ ha) of WRF-7 triticale in 145 demonstration in 2005-06 and 228 demonstration in 2006-07 of NW, central and SW six districts of Bangladesh 
During 2005-06, $5.0 \mathrm{t}$ of WRF-7 triticale seed were produced and stored at the Regional Wheat Research Sub-station, Rajbari, Dinajpur and the Regional Agricultural Research Station, Jamalpur for the 2006-07 program. A total of $6.3 \mathrm{t}$ of WRF-7 seed and $0.6 \mathrm{t}$ seed of several new triticale advanced lines were produced at the same locations in 2006-07. This seed will be used to continue the demonstration program and to give to other farmers that approached DLS or other project staff with interest to grow triticale. Many farmers also preserved seed for planting. 20.4 $t$ was retained for planting in 2007-08 while $23.6 \mathrm{t}$ that was sold or given to other farmers potentially available for planting.

During March 2006, information was collected from triticale growers of 2005-06 on benefit to feed triticale fodder, grain and straw to the cattle. Almost $100 \%$ growers reported that the milk yield was increased and quality of milk was improved during triticale feeding (Table 1). They also reported that cattle health was improved during triticale fodder, grain and straw feeding period (Table 1). In general farmers are reluctant to spare land for fodder cultivation of their cattle due to land scarcity during rabi season. In between Aman rice harvest and boro rice establishment there is a fallow period for an about 50 to 65 days. Thirty growers reported (Table 1) that they could easily fit triticale fodder crop in that fallow period and able to harvest about 20-30 t/ha of fresh triticale quality fodder for their cattle without sacrificing boro crop land.

Table 1. Farmers' feedback on triticale production and utilization, 2005-06

\begin{tabular}{l|ccc|c|c}
\hline \multirow{2}{*}{ Feedback } & \multicolumn{3}{c|}{ Percent of total respondent) } & \multirow{2}{*}{ Total } \\
\cline { 2 - 5 } & Pabna & Rangpur & Joypurhat & Shirajgonj & \\
\hline Improved milk quality & 55 & 36 & 36 & 20 & 147 \\
Increased milk production & $(100 \%)$ & $(100 \%$ & $(100 \%$ & $(95 \%)$ & $(99 \%)$ \\
& 55 & 35 & 35 & 20 & 145 \\
Improved cows health & $(100 \%)$ & $(97 \%)$ & $(100 \%)$ & $(95 \%)$ & $(99 \%)$ \\
& 55 & 37 & 34 & 20 & 146 \\
Get fodder and grain simultaneously & $(100 \%)$ & $(100 \%)$ & $(94 \%)$ & $(95 \%)$ & $(98 \%)$ \\
Get an extra quality fodder crop in lean & 51 & 10 & 17 & 14 & 92 \\
winter season & $(93 \%)$ & $(18 \%)$ & $(41 \%)$ & $(74 \%)$ & $(54 \%)$ \\
Wanted to grow triticale in 2006-07 & $(0 \%)$ & $(33 \%)$ & $(27 \%)$ & $(0 \%)$ & $(18 \%)$ \\
season & 54 & 37 & 36 & 18 & 145 \\
\hline
\end{tabular}

Feedback was also collected from triticale growers related to problems to grow triticale. Seventy-nine growers reported few problems they observed to grow triticale (Table 2), i.e., irrigation problem, bird and rat attack, etc. These are very common problems for most of the rabi season crop production in Bangladesh. 
Table 2. Triticale growers' feedback to identify major problems to grow triticale, 2005-06

\begin{tabular}{lccccc|c}
\hline \multirow{2}{*}{ Feedback } & \multicolumn{2}{c|}{ District-wise respondent (\% of total respondent) } & \multirow{2}{*}{ Total } \\
\cline { 2 - 5 } & Pabna & Rangpur & Joypurhat & Shirajgonj & \\
\hline Needed irrigation & 14 & 11 & 0 & 13 & 38 \\
Bird attack & $(34 \%)$ & $(65 \%)$ & $(0 \%)$ & $(93 \%)$ & $(48 \%)$ \\
Rat attack & 14 & 1 & 1 & 0 & 16 \\
& $(34 \%)$ & $(6 \%)$ & $(14 \%)$ & $0 \%)$ & $(20 \%)$ \\
Difficult to manage & 12 & 0 & 0 & 0 & 12 \\
& $(29 \%)$ & $(0 \%)$ & $(0 \%)$ & $(0 \%)$ & $(15 \%)$ \\
Unavailability of suitable land & 0 & 2 & 0 & 0 & 2 \\
& $(0 \%)$ & $(12 \%)$ & $(0 \%)$ & $(0 \%)$ & $(2.5 \%)$ \\
Un available of seed & 0 & 0 & 5 & 0 & 5 \\
& $(0 \%)$ & $(0 \%)$ & $(71 \%)$ & $(0 \%)$ & $(6 \%)$ \\
Weeding problem & 0 & 1 & 0 & 0 & 1 \\
& $(0 \%)$ & $(6 \%)$ & $(0 \%)$ & $(0 \%)$ & $(1 \%)$ \\
Insect problem & 0 & 1 & 0 & 0 & 1 \\
& $(0 \%)$ & $(6 \%)$ & $(0 \%)$ & $(0 \%)$ & $(1 \%)$ \\
Fodder needs to be harvested & 0 & 0 & 1 & 0 & 1 \\
at a time & $(0 \%)$ & $(0 \%)$ & $(14 \%)$ & $(0 \%)$ & $(1 \%)$ \\
Sribble and red colour grain & 0 & 1 & 0 & 0 & 1 \\
& $(0 \%)$ & $(6 \%)$ & $(0 \%)$ & $(0 \%)$ & $(1 \%)$ \\
Lots of questions came from & 0 & 0 & 0 & 1 & 1 \\
neighbours due to new crop & $(0 \%)$ & $(0 \%)$ & $(0 \%)$ & $(7 \%)$ & $(1)$ \\
\hline Total & $(2 \%)$ & 0 & 0 & 0 & 1 \\
& 41 & $(0 \%)$ & $(0 \%)$ & $(0 \%)$ & $(1 \%)$ \\
\hline
\end{tabular}

\section{DISCUSSION}

The training and demonstration program described with WRF-7 dual-purpose in Bangladesh from 2005 to 2007 has shown great production potential and dairy farmers' interest in the crop, both for quality fodder production during the lean Rabi season for feeding to dairy cows and increasingly as an animal feed and human food grain. Farmers were very interested to learn about how to grow and use the crop. They were saving WRF-7 seed to sow in subsequent seasons and for sale to interested neighbours. After they had experienced producing and using triticale, there was a high level of interest by farmers in continuing to grow and expand triticale plantings, in better ways to produce the crop and in additional innovative ways to use it. Triticale growers' survey of 2006 shows that out of the 149 growers, 145 growers (97\%) wanted to grow triticale in 2006-07 season (Table 1 and Table 3). 
Table 3. District-wise distribution of triticale growers of 2005-06 reported to grow triticale in 2006-07

\begin{tabular}{l|c|c|c|c|c}
\hline \multirow{2}{*}{ District } & \multirow{2}{*}{$\begin{array}{c}\text { No. of } \\
\text { respondent }\end{array}$} & \multicolumn{4}{|c}{ Area reported (ha) to grow triticale in 2006-07 } \\
\cline { 4 - 5 } & & Total & \multicolumn{2}{|c|}{ Ranging } & Average (ha) \\
\cline { 3 - 5 } & & & From (ha) & To (ha) & \\
\hline Pabna & 54 & 10.88 & 0.08 & 0.40 & 0.20 \\
Rangpur & 37 & 8.46 & 0.08 & 0.80 & 0.23 \\
Joypurhat & 36 & 6.02 & 0.06 & 0.40 & 0.17 \\
Shirajgonj & 18 & 2.29 & 0.04 & 0.26 & 0.13 \\
\hline
\end{tabular}

Achieved fodder yields with WRF-7 were 76\% higher in 2005-06 and 267\% higher in 2006-07 than those measured in 2001-02. The improved yields of high quality green fodder achieved by farmers in 2005-06 and 2006-07 was largely because the farmers managed their crops better after receiving training in the project. The very high fodder yields in 2006-07 were additionally due to a favourable long cool rabi season that year. More farmers were observed to measure fodder yields in the early morning when plants were often wet from dew, adding $15-20 \%$ extra moisture to the harvested triticale fodder. The grain yields were almost identical in both 2001-02 and 2005-06, but in 2006-07 grain yield (ranging from 1.19 to 5.93) was much higher due to the crop was managed properly and the single fodder harvest at 40-42 DAS. The favourable long cool Rabi season in 2006-07 contributed to the high grain and straw yield of WRF-7.

Information on the magnitude of triticale benefits on milk and poultry production are emerging from related work. A feeding trial at BLRI, Savar station showed a large (46\%) increase in cow live weight gain and a 36\% increase in milk yield (but no change in milk quality or dry matter intake) in cows fed triticale silage compared with those fed rice straw over a period of nine weeks (Sarker et al., 2007a). In another feeding trial, triticale grain was a good replacement for wheat in the feed blend for chickens in Bangladesh (Sarker et al., 2007a). The average daily live weight gain of cows in the silage group $(1.27 \mathrm{~kg} / \mathrm{d})$ was significantly $(\mathrm{p}<0.05)$ higher than those fed rice straw $(0.87 \mathrm{~kg} / \mathrm{d})$. Many farmers reported $30-100 \%$ increased milk yields during December 2005, January and February 2006 while feeding triticale fodder (Sarker et al., 2007a).and similar benefits in 2006-07.

An assessment of the broader economic and other benefits that smallholder dairy farmers achieve from using triticale as a fodder and for grain is needed and such work is now underway. Costs of production for dual-purpose triticale were similar to those for wheat and maize, but lentil costs were lower. Dual-purpose triticale for fodder and grain had the highest gross return of several enterprise options studied. Dual-purpose triticale increased the profitability of small farms with a few cows. A farm can earn additional net farm income of Taka 3400 with two dairy cows for 30 days (Alam et al., 2007). One major drawback with triticale is that it can only be grown during the cool November-February period, producing green fodder in December and January in Bangladesh. However, fodder shortages persist during February to May. Some triticale can be dried as hay for later use and the straw can be also fed later on. However, maize is another multi-purpose 
fodder and feed for the lean season that is more flexible in planting time throughout Bangladesh. Maize is rapidly expanding as a grain crop in the country and can provide large amounts of green fodder and silage after triticale has finished. Future work should examine fodder production systems that combine staggered plantings of triticale followed by fodder maize to assure farmers of fodder throughout the fodder lean season.

In conclusion, results of the study indicate that WRF-7 triticale variety is promising for the production of quality fodder and feed for dairy cows and poultry farms in North West Bangladesh during the period of fodder shortages. Introduction of promising new triticale lines will increase production further, as will use of improved crop management practices. Given the good yields and farmer interest, and continued difficulties with wheat production, prospects for significant triticale grain production for human food are very good in Bangladesh and a larger promotion and awareness initiative on this is recommended.

\section{ACKNOWLEDGEMENTS}

The authors are grateful to the late Dr. Sufi M Ahmed and Dr. Craig Meisner for initial on-farm research that led to the promotion initiative reported here. Special thanks to DANIDA for funding the work.

\section{REFERENCES}

AFRC (Agriculture and Food Research Council), 1995. Energy and protein requirements of ruminants. An advisory manual. AFRC Technical Committee on Responses to Nutrients. Wallingford UK: CAB International.

Ahmed, S. M., Meisner, C. A. 2002. Report of on-farm triticale demonstrations in Bangladesh. Dhaka, Bangladesh: CIMMYT Natural Resources Group. 20 p.

Alam, J., Akteruzzaman, M., Mezbah Uddin, M. and Rahman, A. 2007. Measuring the befits of triticale as feeds and fodder for dairy production in Bangladesh. Research Report, CIMMYT, Dhaka, Bangladesh.

Andrews, A. C, Wright, R., Simpson, P. G., Jessop, R., Reeves, S., Wheeler, J. 1991. Evaluation of new cultivars of triticale as dual-purpose forage and grain crops. Aust J Exp Agric. 31: 769-775.

Belaid, A. 1994. Nutritive and economic value of triticale as a feed grain for poultry. Mexico DF, Mexico: CIMMYT Economics Working Paper nr. 94-01. 42 p.

Flores, M. P., Castañon, J. I. R., McNab, J. M. 1994. Nutritive value of triticale fed to cockerels and chicks. British Poultry Science, 35: 527-536.

Gentinetta, E., Giammona, M., Delogu, G., Maggiore, T., Lorenzoni, C. 1983. Triticale ed altri cereali a semina autunnale: Confronto qualitativo del prodotto della pianta intera e delle sue parti. Rivista di Agronomia, 17(3): 392-396.

Gohl, B. 1981. Tropical feeds: Feed information summaries and nutritive values. FAO Animal Production and Health Series nr 12. Rome, Italy: Food and Agriculture Organization of the United Nations.

Haque, M. E., Sufian, M. A., Waddington, S. R., Sarker, Z. I., Sarker, N. R., Meisner, C. A. 2007. Triticale is a quality fodder, feed and food for small-scale farmers in Bangladesh. In: Proceedings of the $6^{\text {th }}$ International Triticale Symposium, 3-7 September 2006, Stellenbosch, South Africa. Forthcoming. 
Jahan, M. A. H. S., Amin, M. R., Barma, N. C. D., Babar, M. A., Bodruzzaman, M. 2001. Effect of planting date and forage cutting on the growth and yield of triticale. Bangladesh J. Agric. Res., 26: 297-302.

Meisner, C. A., Sufian, A., Baksh, E., Smith, M., O’Donoghue, Razzaque, M. A. and Shaha, N. K. 2003. Whole family training and adoption of innovations in wheat-producing households in Bangladesh. Journal of Agricultural Education and Extension., 9(4): 165-175.

Mosimann, E. 1998. Seigle et triticale fauches en vert. Revue Suisse d'Agriculture, 30(2): 57-59.

Saadullah, M. 2002. Smallholder dairy production and marketing in Bangladesh. In: Rangnekar D, Thorpe W, editors. Smallholder dairy production and marketing- Opportunities and constraints. Nairobi, Kenya: NDDB (National Dairy Development Board) and ILRI (International Livestock Research Institute). p. 7-21.

Sarker, N. R., Haque, M. E., Huque, K. S., Huque, Q. M. E. and Waddington, S. R. 2007a. Triticale fodder and grain utilization by dairy cattle and poultry in Bangladesh. In: Proceedings of the $6^{\text {th }}$ International Triticale Symposium, 3-7 September 2006, Stellenbosch, South Africa. Forthcoming.

Sarker, Z. I., Waddington, S. R., Sufian, M. A., Haque, M. E., and Hoque, M. A. 2007b. Triticale fodder and grain production by small-scale dairy farmers in North West Bangladesh. In: Proceedings of the $6^{\text {th }}$ International Triticale Symposium, 3-7 September 2006, Stellenbosch, South Africa. Forthcoming.

Sufian, M. A. 1979. Varietal performance of barley, wheat and triticale. Bangladesh Journal of Agriculture, 4(1): 57-59.

Varughese, G., Pfeiffer, W. H. and Peña, R. J. 1997. Triticale: A reappraisal. http:/www.worldbank. org/html/cigar/newsletter/april97/8tritic.html 